\title{
CARACTERIZAÇÃO MICROCLIMÁTICA DOS MANGUEZAIS DA BARRA DO RIBEIRA-IGUAPE/SP E SUAS RELAÇÕES COM OS ASPECTOS FISIONÔMICOS DA VEGETAÇÃO
}

\author{
Emerson Galvani**
}

Nádia G. B. de Lima*

\section{RESUMO:}

As pesquisas desenvolvidas na área de climatologia têm sido, voltadas para a escala regional e local. Entretanto, devido à atenção dada, atualmente, aos estudos ambientais e, com isso, à necessidade de estudos em escalas inferiores do clima, com análises mais detalhadas, os estudos microclimáticos acabaram ganhando destaque. Os manguezais que se destacam no Sistema Costeiro Cananéia-Iguape representam comunidades vegetais adaptadas a várias condicionantes físicas atuantes nas zonas costeiras, entre elas, as climáticas. Neste sentido, a vegetação de uma determinada área está relacionada às características físicas, químicas e biológicas do meio em que está inserida. Assim, a presente pesquisa tem como finalidade realizar uma análise fisionômica da vegetação de manguezal, identificando a relação existente entre as principais características físicas do ambiente, com destaque aos aspectos microclimáticos. Ao comparar os dados estruturais da vegetação e relacioná-los com os atributos climáticos, confirmou-se a importância da vegetação como controlador climático, principalmente quando a escala de trabalho é a microclimática.

PALAVRAS-CHAVE:

microclima, manguezal, atributos e controles climáticos, Barra do Ribeira.

\section{ABSTRACT:}

The researches developed on the climatology have been in their majority, turned to the region and local scale. Nevertheless, due to the attention that have been given to the environmental studies nowadays, and the necessity of studies in inferior climate's scales, with detailed analysis, the microclimatic studies gained eminence. The mangroves that have eminence in the Cananéia - Iguape Costal System represent the vegetable community adapted to various physical conditioning in operation in the costal zones, among its, the climatic. Therefore, the vegetation of one determined area is related to the physical, chemical and biological characteristics of the environment that it's inserted. Afterward, this research has the purpose to realize the mangrove vegetation's phisionomic analysis and to identify the relation existent between the principal physical characteristics of the environment, eminently to the microclimatic factor, aiming the comprehension of the active dynamic along the Cananéia - Iguape Costal System. When comparing the structural data of the vegetation and relating them with the climatic attributes, the importance of the vegetation was confirmed it as controlling climatic, mainly when the work scale is the microclimatic one.

\section{KEY WORDS:}

*Geógrafa - Departamento de Geografia - FFLCH - USP. Laboratório de Climatologia e Biogeografia - LCB. E-mail: nadiagilma@yahoo.com.br **Prof. Dr. do Departamento de Geografia - FFLCH - USP. Laboratório de Climatologia e Biogeografia - LCB. E-mail: egalvani@usp.br 


\section{Introdução}

As pesquisas desenvolvidas na área da Climatologia têm sido, em sua maioria, voltadas para a escala regional e local. No entanto, devido à atenção dada, atualmente, aos estudos ambientais e, com isso, a necessidade de estudos em escalas inferiores do clima, com análises mais detalhadas, os estudos microclimáticos acabaram ganhando destaque, com o objetivo de entender, de forma integrada, os aspectos físicos, principalmente em áreas prioritária para preservação, como o Sistema Costeiro Cananéia-lguape, que é considerado uma das áreas mais preservadas do estado de São Paulo.

Os manguezais, com importante destaque na área de estudo, constituem unidades ecológicas de função especializada, por sua característica fundamental de ambiente salinizado e pela constante inundação causada por marés. Sua importância maior está relacionada à produção de biomassa, qu é introduzida no sistema bioenergético natural aumentando a produtividade da zona costeira através da introdução de particulados orgânicos, pelos processos químicos e biológicos na águas estuarino-lagunares (HERZ, 1988). Representam comunidades vegetais aadaptadas a várias condicionantes físicas atuantes nas zonas costeiras, entre elas, as climáticas.

Por se tratar de um ambiente de elevada fragilidade natural aos processos de ocupação humana, dadas as características de relevo plano, solos arenosos e inconsolidados, lençol freático próximo à superfície, elevada biodiversidade e berçário para a reprodução de inúmeras espécies animais, a área está toda delimitada como unidade de conservação ambiental e sob olhar dos órgãos gestores ambientais. É, portanto, uma unidade ambiental de absoluto interesse a preservação e conservação ambiental, mas também favorável às atividades do turismo ecológico, pesca, balneário e históricocultural (ROSS, 2002).

O estudo em análise detalhada do ecossistema acima exposto se justifica a partir da necessidade de melhor entender o ambiente em escalas inferiores, sendo de fundamental importância que se considere a inter-relação existente no meio físico, dentro de uma dinâmica do ambiente. Neste sentido, a presente pesquisa tem como finalidade realizar uma análise fisionômica da vegetação de manguezal, identificando a relação existente entre as principais características físicas do ambiente, com destaque aos controles e atributos microclimáticos, visando a compreensão da dinâmica atuante ao longo do Sistema Costeiro Cananéia - Iguape. Por meio dos estudos de escalas inferiores chegar-se-á a um melhor entendimento da área estudada, fundamentando-se num estudo integrado dos aspectos físicos, no intuito de conhecer as relações estabelecidas entre as variáveis do meio físico. Para afirmar a importância do estudo microclimático, basta lembrar que se trata do estudo da camada de ar onde acontece a reprodução da vida.

\section{Área de estudo}

\section{1 - O Sistema Costeiro Cananéia-Iguape}

A área de estudo está localizada no setor nordeste do Sistema Costeiro Cananéia-lguape, drenada pelo curso inferior do Rio Ribeira de Iguape. Segundo Suguio e Tessler (1992), a bacia hidrográfica do Rio Ribeira de Iguape desempenhou importante função nos processos evolutivos da área durante o Quaternário, sendo um dos poucos rios do Estado de São Paulo que ainda apresenta influência continental até bem próximo à sua foz, localizada no município de Iguape, na Barra do Ribeira.

A ilha de Iguape é considerada uma ilha artificial por ter sido originada pela 
abertura, no ano de 1832, de um canal de ligação entre o Mar Pequeno e o Rio Ribeira de Iguape, que recebeu o nome de Valo Grande. A abertura do Valo Grande visava um melhor escoamento da produção de arroz, de forma que se tornasse mais eficaz, já que contribuía para uma melhor navegação no trecho final do Rio Ribeira. Ao término de sua construção, o canal apresentava 4,40 m de largura. Entretanto, devido à erosão nas bordas, o canal apresenta-se, atualmente, com cerca de 300 $m$ de largura, fazendo com que grande parte da vazão do Rio Ribeira escoe por ele, acarretando grande efeito sobre o sistema como um todo (CUNHA-LIGNON, 2001).

O Sistema Costeiro Cananéia-Iguape é considerado um dos mais produtivos e um dos principais locais de abrigo e reprodução de inúmeras espécies marinhas da costa sudeste brasileira. A vegetação característica compõe-se de formações pioneiras tanto de influência marinha (restinga), como de influência fluviomarinha arbórea (mangue), ocupando a faixa litorânea. Nos manguezais, a queda das folhas das árvores e sua mistura com o lodo formam restos orgânicos importantes que servem de base da cadeia alimentar para várias espécies de moluscos, particularmente ostras, crustáceos e peixes.

Nesse sentido, a área de estudo faz parte de um importante complexo estuarino de grande complexidade biofísica, onde ocorre o ecossistema manguezal ao lado das planícies e cordões arenosos marinhos, recortados por planícies fluviais, cujos sedimentos marinhos são retrabalhados pelos rios e acrescidos de outros sedimentos procedentes do interior do continente.

\section{2 - Características do Meio Físico}

A planície costeira de CananéiaIguape exibe uma forma linear, com quase
$40 \times 130 \mathrm{~km}$, delimitado a NE e SW por pontos do embasamento cristalino que avançam oceano adentro, perfazendo uma superfície de quase $2500 \mathrm{~km}^{2}$ (SUGUIO; TESSLER, 1992). Sua evolução desenvolveuse a partir de variações do nível marinho nos últimos $120 \mathrm{mil}$ anos por meio das transgressões e regressões marinhas.

De acordo com Ross (2002), no trecho inferior do Rio Ribeira do Iguape, na Barra do Ribeira, ocorrem as planícies de mangue, que no âmbito geomorfológico estão sempre associadas aos ambientes onde prevalecem extensas áreas de terrenos baixos e planos originados por depósitos marinhos, retrabalhados por processos fluviais e onde ocorre aporte de sedimentos finos continentais (argilas em colóides), que, em áreas de contato com as águas salinas procedentes do oceano pela maré alta, provocam a floculação das argilas e conseqüentemente, a deposição das mesmas.

Quanto ao clima, a nível regional, toda essa área enquadra-se em uma mesma realidade climática: "clima subtropical úmido da fachada oriental da América do Sul". As temperaturas médias anuais oscilam entre 21 ㅇ e 22ㅇ $\mathrm{C}$ para as baixadas, e entre 17 ㅇ e 20 ㄷ para os maciços costeiros litorâneos e sublitôraneos. O regime pluvial não apresenta, em termos médios, período seco definitivo (SMA, 1990).

A vegetação presente na área compõe-se de Floresta Ombrófila Densa, ocupando encostas de morros e serras, e de Formações Pioneiras, tanto de influência marinha (restinga) como de influência fluviomarinha arbórea (mangue), ocupando a faixa litorânea. Os manguezais são considerados o ecossistema mais significativo de todo o Sistema Costeiro Cananéia - Iguape, estendendo-se por cerca de $100 \mathrm{~km}$ (DIEGUES, 2002) (Figura 1). 


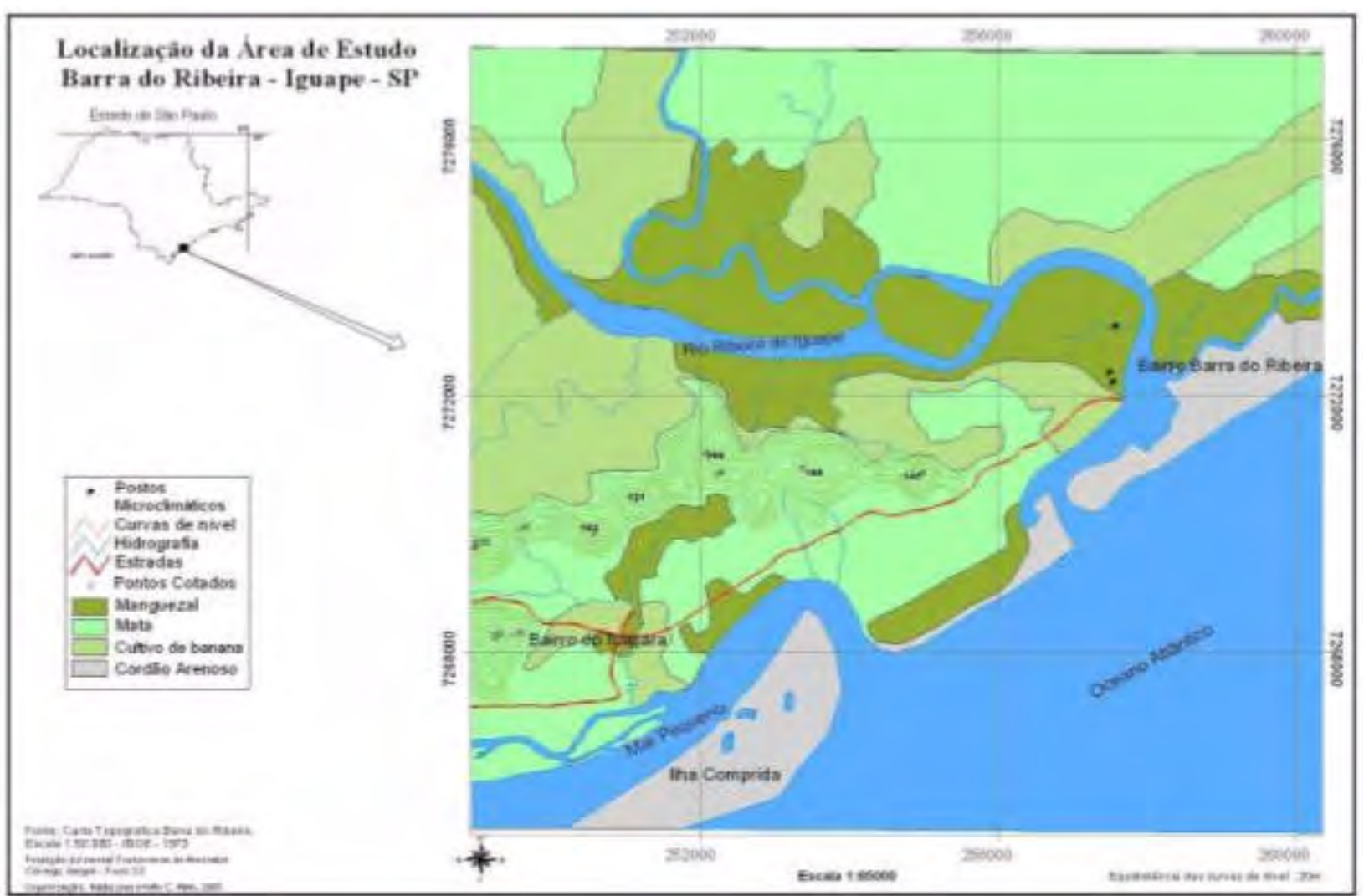

Figura 1: Localização dos Manguezais da Barra do Ribeira - Iguape/SP

\section{3 - Os manguezais}

O manguezal é um ecossistema costeiro, halófito e com desenvolvimento de flora especializada, a qual, exposta a lavagens diárias pelas marés, exporta material particulado (folhas, galhos, propágulos) a ser decomposto nos corpos d'água adjacentes (rios, estuários, águas costeiras) (SCHAEFFER-NOVELLI et al., 1995). Representa comunidades vegetais adaptadas a condicionantes climáticas atuantes nos zonas costeiras, geograficamente distribuídas entre latitudes intertropicais. Para Schaeffer-Novelli et al. (1995), quanto à temperatura e à precipitação pluvial, as condições ideais para o desenvolvimento dos manguezais estão próximas às temperaturas médias acima de 20 드. média das temperaturas mínimas não inferiores a $15 \circ \mathrm{C}$, amplitude térmica anual menor que 5 oC e precipitação pluvial acima de $1.500 \mathrm{~mm} /$ ano, sem prolongados períodos de seca.

Dentre as principais espécies presentes no Brasil, destacam-se: Rhizophora mangle, Rhizophora harrison, Rhizophora racemosaas, Avicennia schauerian, Avicennia germinan, Laguncularia racemosa e Conocarpus erecta.

Quanto à fauna, poucas espécies são exclusivas dos manguezais, tendo sua origem nos ambientes terrestre, marinho e de água doce. A maioria representa população de espécies oportunistas e de ampla distribuição, onde os fatores físico-químicos (salinidade, inundação/ dissecação, características do solo) determinam a estrutura das comunidades, mais que fatores bióticos (CINTRÓN; SCHAEFFER-NOVELLI, 1986). 


\section{Fundamentação Teórico-metodológica}

A presente pesquisa pressupõe a produção de um conhecimento fundamentado na realidade da Barra do Ribeira, mais especificamente nos manguezais, visando entender a relação entre os atributos e controles climáticos, e como estes se refletem no espaço geográfico.

Segundo Sette op. cit., por meio da análise rítmica instituída por Monteiro (1971), e de acordo com Tarifa (1975), os pressupostos teóricos aliados à noção de ritmo e sucessão dos estados atmosféricos demonstram que não são os tipos de tempo isolados que produzem repercussões notáveis no complexo geográfico, mas, sim, as seqüências de tipos de tempo que, em diferentes combinações e interações, formam verdadeiras cadeias, e são essas que exprimem diferentes tipos de ritmo, sendo o ritmo a essência geográfica do clima.

Monteiro (1975), após a adoção do ritmo, introduz a abordagem sistêmica, marcando, também, uma postura ambiental via estudo do clima. A Teoria Geral do Sistema serviu como base para a elaboração do Geossistema, que, segundo Rodrigues (2001), faz parte de um conjunto de tentativas ou de formulações teórico-metodológicas da Geografia Física que surgiram em função da necessidade da Geografia lidar com os princípios de interdisciplinaridade, síntese, com a abordagem multiescalar e com a dinâmica.

Segundo Bertrand (1971), a paisagem não é uma simples adição de elementos geográficos, mas, sim, o resultado da combinação dinâmica de elementos físicos, biológicos e antrópicos em um determinado espaço, interagindo uns com os outros em constante evolução, formando um conjunto único indissociável numa determinada porção do espaço. Para ele, a noção de escala não deve ser separada do estudo das paisagens, devendo ser considerada tanto no espaço quanto no tempo. Define seis níveis de escala têmporo-espaciais, onde os três níveis superiores são a zona, o domínio e a região natural, e os três níves inferiores são o geossistema, a geofácies e o geótopo.
Para Bertrand, op. cit., o geossistema é considerado um complexo essencialmente dinâmico no espaço e no tempo, resultando da combinação de aspectos geomorfológicos, climáticos e hidrológicos. Essa dinâmica interna não resulta, necessariamente, numa homogeneidade fisionômica, mas formada por paisagens diferentes que representam os diversos estágios da evolução do geossistema e que correspondem aos geofácies, um setor fisionomicamente homogêneo, no qual se desenvolve uma mesma fase de evolução geral do geossistema.

Já o geótopo constitui uma das menores unidades escalares de análise geográfica do ambiente, diferenciando-se por suas condições ecológicas, onde a vegetação constitui o indicador mais importante da variação dos ambientes físicos. Mudanças tênues das condições físicas se refletem em alterações nos padrões da vegetação quanto à estrutura, à fisionomia e à composição de espécies. Nessa escala, ocorre uma relação estreita entre associações vegetais específicas e as particularidades físicas no que se refere à posição geográfica, relevo, solo e microclima (DINIZ \& FURLAN, 1998).

Com isso exposto, o presente trabalho pretende seguir essa proposta metodológica, adotando a abordagem sistêmica como fio condutor, levando em consideração que a Geografia tem como um dos seus objetivos entender a inter-relação existente no meio físico entre os fatores bióticos e abióticos, considerando a variável espacial, com o intuito de compreender a dinâmica do ambiente. Quanto à escala de trabalho, dentro da proposta de Bertrand (1971), o presente estudo se enquadra no geótopo, na qual está inserida o estudo de microclima relacionado aos demais aspectos físicos.

\section{Materiais e Métodos}

\section{1) Levantamento dos principais controles climáticos}

\section{Vegetação}

A vegetação é um dos principais controles climáticos para a determinação de microclima, já que 
estes estão essencialmente ligados ao uso e/ou cobertura do solo. Nessa pesquisa, a vegetação foi trabalhada a partir de uma análise fisionômica, com levantamento de suas principais características estruturais. Para isso, delimitaram-se três parcelas de $10 \times 10 \mathrm{~m}$, de acordo com medidas e parâmetros propostos por Cintrón e Schaeffer-Novelli (1986).

As medidas de diâmetro foram obtidas a 1,30 $\mathrm{m}$ do solo, realizadas em plantas com mais de $1 \mathrm{~m}$ de altura, sendo registradas em fichas de campo, organizadas em colunas por classes de DAP $=2,5$ $\mathrm{cm}$ (pequena); entre $=2,5 \mathrm{~cm}=10 \mathrm{~cm}$ (intermediária); e $=10 \mathrm{~cm}$ (elevada).

A área basal (g), definida como a área ocupada por um tronco com um dado diâmetro, é dada por: $\mathrm{g}=\mathrm{nr} 2$, onde $\mathrm{g}$ é a área basal e $\mathrm{r}$ é o raio, mas como $r=\mathrm{DAP} / 2$, então, em termos de diâmetro, $g$ é dado por: $g=n D A P 2 / 4$. Para expressar $\mathrm{g}$ em termos de $\mathrm{m}^{2}$ quando se mede o diâmetro em centímetros, se utiliza a seguinte fórmula: $\mathrm{g}=\mathrm{n}$ (DAP2) / 4 (10.000), ou seja, g (m2) $=0,00007854$ (DAP cm) 2 .

Com os dados levantados pôde-se obter a densidade relativa (número de árvores por unidade de área) e a dominância relativa (que representa o espaço ocupado pela espécie na comunidade das espécies), pelas equações:

$\mathrm{DR}=(\mathrm{n}$ - de indivíduos da espécie i / no total de indivíduos amostrados) X 100. total $\times 100$

DoR = Área Basal da espécie i / Área Basal

O diâmetro médio é definido como sendo o diâmetro da árvore de área basal média. A área basal da árvore média é dada pela expressão:

$(\mathrm{g})$ = área basal por hectare $(\mathrm{g})$ / no de árvores por hectare.

Como a área basal é igual a: $g=\left(D^{2} P^{2}\right)$ $(0,00007854)$, então o diâmetro médio (DAP) é dado por:

$$
\text { ??!?!?DAP = ? (g) }(12732,39)
$$

\section{$\underline{\text { Sedimentos }}$}

As características do solo também são de especial relevância na determinação de microclimas, pois a energia que incidir sobre a superfície será absorvida, refletida, transmitida e emitirá radiação em função de suas propriedades (formas, côres) e constituição (materiais de composição - tecidos vegetal, solo exposto, rocha exposta, etc.). Para a caracterização dos sedimentos presentes na área de estudo foram realizadas coletas visando a análise da textura e da cor.

\section{Marés}

Quanto à maré, utilizou-se tábuas de marés obtidas pelo site da Diretoria de Navegação e Hidrologia (DHN), de responsabilidade da marinha. Esses dados subsidiaram as idas ao campo, pois as tábuas de marés prevêm os horários de maré baixa e de maré alta, contribuindo para que o acesso à área de estudo ocorresse em períodos de maré baixa, como forma de viabilizar o acesso à área.

\section{2) Levantamento dos principais atributos climáticos}

Temperatura do ar e Umidade relativa do ar

A temperatura do ar e a umidade relativa do ar foram obtidas através de miniregistradores digitais (dataloggers), programados no computador pelo software Boxcar-pró, fornecido pelo fabricante e instalados em abrigo meteorológico de ventilação passiva (ARMANI, 2004). O datalogger de temperatura do ar registra no intervalo de -50 a $\pm 37 ㅇ$ C. Entretanto, nessa pesquisa os sensores apresentaram medidas superiores a esse intervalo, que foram confirmadas pelas medições da PCDIguape (CPTEC/INPE), que também registrou valores extremos para o mesmo dia.

Para que fossem realizadas as correções dos sensores, no dia 10/08/05 programou-se os oitos sensores (quatro de temperatura do ar e quatro de umidade relativa do ar) para o registro de hora em hora, a partir das 21 horas, os quais foram deixados dentro de uma sala no Laboratório de Climatologia e Biogeografia - Departamento de Geografia/USP, 
Caracterização microclimática dos manguezais da Barra do Ribeira-Iguape/SP

e suas relações com os aspectos fisionômicos da vegetação, pp. 79 - 100

de forma que permanecessem sobre as mesmas condições atmosféricas. Os sensores foram levados a campo no dia $13 / 08 / 05$, onde permaneceram durante um período de dois meses (15/08 a 14/10/ 05).

Posteriormente, os dados foram descarregados utilizando-se o software Boxcar-pró, fornecido pelo fabricante e transferidos para o software Microsoft Excel, onde foram trabalhados para análise dos resultados. Primeiramente, foram avaliadas as consistências dos dados no período reservado para a calibragem dos sensores, 10/08/ 05 a 13/08/05; a partir de então, com auxílio de um gráfico de linhas, escolheu-se como padrão o sensor que estava operando entre os valores de temperatura e umidade que registraram os extremos (maior e menor). Nesse caso o sensor escolhido como padrão foi o P1. A variação entre os sensores de temperatura do ar de um abrigo e outro oscilaram entre $\pm 0,10^{\circ} C$, portanto abaixo do êrro instrumental aceito, que é de $\pm 0,25 \circ \mathrm{C}$, portanto, não precisando de correções, e, para a umidade relativa do ar, a variação entre os sensores de um abrigo e outro oscilaram entre $\pm 1 \%$, também abaixo do erro instrumental aceito, que é de $\pm 5 \%$, não tendo sido necessária nenhuma correção nos sensores de umidade.

\section{Radiação Solar.}

Pretendeu-se quantificar a radiação global e a radiação refletida (onda curta) registrada em dois pontos do ecossistema manguezal da Barra do Ribeira. Para isso, utilizou-se um Piranômetro de termopar Eppley. Neste instrumento, o elemento sensor é uma placa com uma série de termopares (termopilha), onde parte das junções é enegrecida (junções "quentes") e parte é branca (junções "frias"). O aquecimento diferenciado das junções "quentes" e "frias" gera uma força eletromotriz (f.e.m), cuja magnitude é registrada por meio de um multímetro. A placa sensora é protegida por uma cúpula de quartzo, que filtra as radiações de onda longa, sendo atingida apenas pela radiação solar (ondas curtas).

\section{Pluviosidade.}

A pluviosidade é um dos atributos que mais contribui para o desenvolvimento dos manguezais. Para a pesquisa em questão, resolveu-se confeccionar os pluviômetros, já que não se dispunha de dados referentes ao ambiente manguezal. Para isso, foram seguidos os procedimentos determinados por Milanesi e Galvani (2005) para a confecção de pluviômetros para localidades remotas, de difícil acesso, com alta durabilidade e viáveis economicamente.

\section{3) Os Postos Microclimáticos}

A escolha da localização dos postos microclimáticos se deu com a realização de um primeiro trabalho de campo, realizado nos dias 05 e 06 de maio de 2005. As instalações dos postos ocorreram nos dias 13 e 14 de agosto de 2005, após o levantamento e preparação dos equipamentos (Figura 2).

Posto 1: instalado nas coordenadas UTM $257.590 \times 7.272 .050$, em área de manguezal sem a presença de espécies arbóreas que formassem dossel. Foi instalado um abrigo meteorológico contendo dois dataloggers (temperatura do ar e umidade relativa do ar) e um pluviômetro (PL1).

Postos 2 e 3: instalados sobre as mesmas coordenadas UTM $257.530 \times 7.272 .320$, constituíram - que se convencionou chamar de "torre microclimática", composta por dois pares de dataloggers de temperatura do ar e umidade relativa do ar, além de um pluviômetro. Para a elaboração da "torre microclimática", adquiriu-se uma barra de ferro de $5 \mathrm{~m}$, que foi fixada a uma madeira enterrada no substrato lodoso do mangue. A barra de ferro foi amarrada na madeira a uma altura de $1 \mathrm{~m}$ do solo, fazendo com que a altura máxima da torre atingisse 6 metros. P2 foi instalado a 1,30 m de distância do solo, contendo um par de sensores de temperatura e umidade relativa, enquanto $P 3$ foi instalado na extremidade da barra de ferro, contendo um sensor de temperatura do ar e outro de umidade relativa, de forma a ultrapassar o dossel do bosque, com aproximadamente 6 metros de altura. Com isso foi possível comparar os dados obtidos fora e dentro 
do manguezal, caracterizando-os verticalmente. Instalou-se, ainda nesse posto, um pluviômetro (PL2) visando determinar a quantidade de chuva que chegou no interior desse ambiente.

Posto 4: instalado nas coordenadas UTM $257.350 \times 7.272 .650$, próximo à margem de um afluente do Rio Ribeira, no qual se instalou o quarto abrigo meteorológico contendo um par de sensores, tanto de temperatura do ar quanto o de umidade relativa do ar. Esse posto tem como característica marcante a presença de um dossel denso e fechado,

sendo também mais influenciado pela ação da maré, pois está localizado à margem de um curso d'água.

PCD-Iguape: Os postos microclimáticos foram comparados com dados da Estação Meteorológica Automática do Centro de Previsão do Tempo e Estudos Climáticos (CPTEC), a Plataforma de Coleta de Dados (PCD), de responsabilidade do Instituto Nacional de Pesquisas Espaciais (INPE). A PCD-Iguape está localizada no Colégio Agrícola Narciso de Medeiros, no município de Iguape, sob as coordenadas geográficas $s$ 240-67' e W 470-54', a umpa

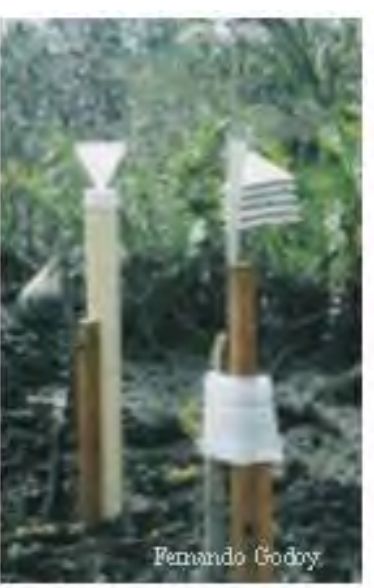

Posto 1

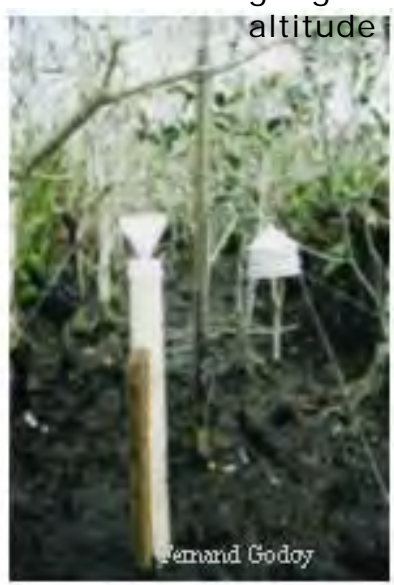

Posto 2

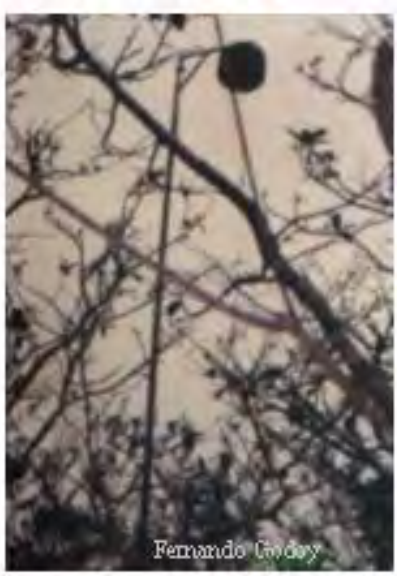

Posto 3

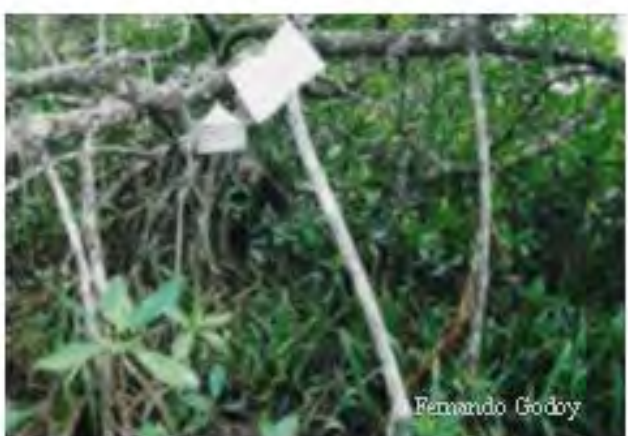

Posto 4

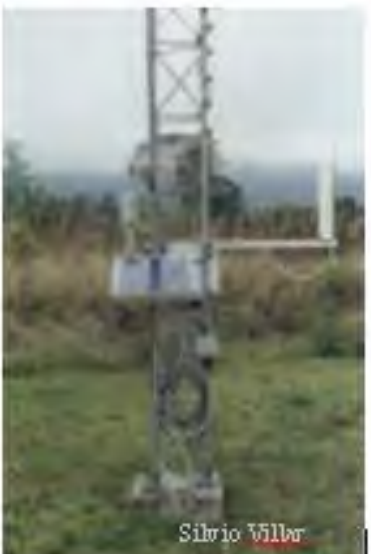

PCD/CPTEC-Iguape

Figura 2: Os Postos microclimáticos instalados no manguezal da Barra do Ribeira e a PCD/ CPTEC- Iguape/SP. 


\section{Resultados e Discussão}

\section{Controles Climáticos}

\section{1) Vegetação}

Para a caracterização dos bosques de mangue utilizou-se a metodologia proposta por Cintrón e Schaeffer-Novelli (1986), realizando-se uma análise fisionômica da vegetação, com levantamento das principais características estruturais do manguezal, sintetizadas na tabela 1 :

\begin{tabular}{|c|c|c|c|c|}
\hline Espécie & $\begin{array}{c}\text { Densidade } \\
\text { Relativa }\end{array}$ & $\begin{array}{c}\text { Dominância } \\
\text { Relativa }\end{array}$ & $\begin{array}{l}\text { Área } \\
\text { Basal }\end{array}$ & $\begin{array}{c}\text { Diâmetro } \\
\text { Médio }\end{array}$ \\
\hline \multicolumn{5}{|c|}{ Parcela $1-73$ indivíduos } \\
\hline Conocarous erecta & $100 \%$ & $100 \%$ & $0,08 \mathrm{~m}^{2} / \mathrm{ha}$ & $2,5 \mathrm{~cm}$ \\
\hline \multicolumn{5}{|c|}{ Parcela $2-80$ indivíduos } \\
\hline Conocarpus erecta & $100,0 \%$ & $100 \%$ & $0,19 \mathrm{~m}^{2} / \mathrm{ha}$ & $4,4 \mathrm{~cm}$ \\
\hline \multicolumn{5}{|c|}{ Parcela $3-20$ indivíduos } \\
\hline Rhizophora mangle & $90 \%$ & $96 \%$ & $0,16 \mathrm{~m}^{2} / \mathrm{ha}$ & $10,6 \mathrm{~cm}$ \\
\hline $\begin{array}{l}\text { Laguncularia } \\
\text { racemosa }\end{array}$ & $10 \%$ & $4 \%$ & $0,006 m^{2} / h a$ & $4,95 \mathrm{~cm}$ \\
\hline
\end{tabular}

Tabela 1: Parâmetros Fitosociológicos para o manguezal da Barra do Ribeira-Iguape/SP

Parcela 1 (P1): foi delimitada de forma que P1 se localizasse no centro da parcela. Essa parcela apresentou, como característica marcante, a presença da samambaias do mangue, gênero Acrostichum. No entanto essas espécies não foram levantadas quantitativamente por apresentarem, na área de estudo, menos de $1 \mathrm{~m}$ de altura. A segunda espécie identificada e levantada quantitativamente foi a Conocarpus erecta, também conhecida, popularmente, por mangue botão, apresentando, como características uma pequena estatura, atingindo, no máximo, cerca de $4 \mathrm{~m}$ de altura e folhas alternadas, com pecíolos curtos e alados. O sistema radicular não está adaptado à vida em terrenos alagados e salgados; são plantas que crescem em locais somente atingidos por preamares excepcionais, localizadas em zonas de transição com terra firme.

Conforme tabela 1, foram amostrados, nessa parcela, 73 indivíduos da espécie Conocarpus erecta, apresentando uma área basal total de $0,08 \mathrm{~m}^{2} / \mathrm{ha}$, diâmetro médio de $2,5 \mathrm{~cm}$ e altura média do bosque de $2,33 \mathrm{~m}$. Essa espécie apresentou uma maior contribuição de troncos com diâmetros ? 2,5cm, com 96 troncos, representando uma área basal de 0,022 $\mathrm{m}^{2} / \mathrm{ha}, 65$ troncos com diâmetros ? 2,5 $\mathrm{cm}$, equivalendo a uma área basal de $0,059 \mathrm{~m}^{2} /$ ha, e nenhum tronco com diâmetros ? $10 \mathrm{~cm}$. Por apresentar apenas uma espécie, a Conocarpus erecta, a Densidade Relativa e a Dominância Relativa na Parcela 1 foi de $100 \%$.

A Parcela 1 apresentou um bosque de menor desenvolvimento estrutural, com menor área basal e diâmetro médio inferior a $2,5 \mathrm{~cm}$. As espécies dessa parcela apresentaram ainda uma elevada quantidade de ramificações, num total de 161 troncos para 73 indivíduos, comprovando a imaturidade do bosque.

Parcela 2 (P2 e P3): foi delimitada de forma que a "torre microclimática" (P2 e P3) estivesse localizada no centro da parcela. Essa parcela apresentou, em seus limites, também, 
destaque para a espécie Conocarpus erecta, apesar de também apresentar algumas espécies de samambaias do mangue e espécies de epífitas. Foram amostrados 80 indivíduos de Conocarpus erecta, com uma área basal de 0,19 $\mathrm{m}^{2} / \mathrm{ha}$, diâmetro médio de $4,4 \mathrm{~cm}$ e altura média do bosque de 2,63 m. Essa espécie apresentou uma maior contribuição de troncos com classe diamétrica? 2,5 cm, com 110 troncos, correspondendo a uma área basal de 0,182 $\mathrm{m}^{2}$ / ha; apresentou ainda 10 troncos com classe diamétrica ? 2,5 cm, com área basal de 0,003 $\mathrm{m}^{2} /$ ha e nenhum tronco ? $10 \mathrm{~cm}$. A Densidade Relativa e a Dominância Relativa na Parcela 2 também foi de $100 \%$. A parcela 2 apresentou a maior área basal, com uma presença elevada de indivíduos, porém seu diâmetro apresentou valores intermediários, com $4,4 \mathrm{~cm}$. Durante o período de levantamento de dados, o mangue botão (parcela 1 e 2) apresentou um período de trocas de folhas, sendo alguns de seus indivíduos encontrados em processo de perda de folhas, com características de folhas velhas, endurecidas e amareladas, enquanto outros já se encontravam com folhas novas, pequenas e bastante esverdeadas, o que provavelmente influenciou as características microclimáticas dos postos onde está espécie foi encontrada.

Parcela 3: foi delimitada de forma que P4 se localiza-se no centro da parcela. Essa parcela apresentou, em seus limites, duas espécies principais, a Rhizophora mangle e a Laguncularia racemosa, caracterizando-se assim por um bosque misto.

Foram amostrados 20 indivíduos, dos quais 18 pertencem a espécie Rhizophora mangle (mangue vermelho) e 2 pertencem à espécie Laguncularia racemosa (mangue branco). A espécie de Rhizophora mangle apresentou uma área basal de 0,16 $\mathrm{m}^{2} / \mathrm{ha}$, diâmetro médio de $10,6 \mathrm{~cm}$ e altura média do bosque de $6,78 \mathrm{~m}$. Essa espécie apresentou uma maior contribuição de troncos com classe diamétrica ? $10 \mathrm{~cm}$, com 11 indivíduos, correspondendo a uma área basal de 0,137 $\mathrm{m}^{2} / \mathrm{ha}, 5$ indivíduos com diâmetros ? 2,5 cm, com 0,021 $\mathrm{m}^{2} / \mathrm{ha}$ de área basal e apenas 2 troncos com diâmetros ? 2,5 cm, correspondendo a 0,0005 $\mathrm{m}^{2} / \mathrm{ha}$. A espécie Laguncularia racemosa apresentou uma área basal de 0,006 $\mathrm{m}^{2} / \mathrm{ha}$, DAP médio de 4,95 $\mathrm{cm}$ e altura média do bosque de $3,25 \mathrm{~m}$. Essa espécie apresentou apenas 3 troncos com classe diamétrica ? 2,5 cm. Quanto a Densidade Relativa, a Parcela 3 apresentou para a Rhizophora mangle $90 \%$, enquanto para a Laguncularia racemosa apresentou $10 \%$. Já quanto a Dominância relativa, a Rhizophora mangle apresentou $96 \%$ contra $4 \%$ da Laguncularia racemosa.

A parcela 3 possui um elevado desenvolvimento em relação às demais parcelas, sendo, também, a única parcela que apresentou um bosque misto. As espécies apresentaram ainda, uma pequena quantidade de ramificações, a Rhizophora mangle apresentou um total de 18 troncos e a Laguncularia racemosa apresentou um total de 3 troncos, comprovando a maturidade do bosque.

\section{2) Sedimentos}

Para a caracterização dos sedimentos, coletaram-se amostras superficiais em P1 e na torre microclimática (P2 e P3). Infelizmente não foi possível realizar coleta em P4, pois, devido às condições de chuva intensa e ação da maré alta, o solo permaneceu em período de inundação durante os dias em que se realizou campo para essa coleta (17/09/05 e 15/10/05). Os sedimentos coletados nos dois postos caracterizam-se por uma consistência pastosa, são pegajosos e ricos em matéria orgânica. Em campo apresentaram-se muito pouco compactos, sujeitos a períodos alternados de inundação pela maré. Para a análise de textura, realizada pelo próprio tato, o material foi coletado e esfregado entre os dedos, que, de acordo com Cintrón e Schaeffer-Novelli (1986), apresentando-se áspero e sendo as partículas visíveis, é arenoso. Já os sedimentos argilosos são extremamente plásticos e pegajosos quando 
úmidos e duros quando secos. Com isso, os sedimentos coletados no Posto 1 apresentaram-se bastante plásticos e pegajosos quando úmidos e intensamente duros quando secos, ao contrário do Posto 2, que, apesar de quando úmidos, apresentarem-se pegajosos e plásticos, quando secos desagregaram-se com facilidade, sendo possível a visualização de partículas arenosas, o que, provavelmente, influenciou o microclima dos postos.

Os sedimentos nos dois postos destacaramse por uma coloração preta, tanto para as amostras úmidas como para as secas, demonstrando o caráter dominante dos processos de redução nesses solos. De acordo com Rossi e Mattos (2002), a côr preta pode ser explicada pela presença da matéria orgânica, constantemente depositada e reciclada pela presença constante de água. A cor também influi na temperatura dos mesmos, pois solos escuros absorvem mais calor que os claros, o que vem a influenciar as características microclimáticas do local.

\section{Atributos Climáticos.}

\section{1) Temperatura do ar}

A análise das médias de temperatura do ar de todos os postos indicou que todos oscilaram próximo de $20^{\circ} \mathrm{C}$, aparentando que eles não seriam muito diferentes um dos outros. Entretanto, ao se levar em consideração as temperaturas máximas e mínimas obtidas em cada posto, as diferenças apareceram, comprovando que há diferenças microclimáticas entre os ambientes.

A figura 03 permite verificar que ao se comparar apenas os postos, as mínimas temperaturas absolutas ocorreram em P1, com 11,4 으 C. Isso pode ser explicado pelo fato desse posto estar localizado em área de manguezal, envolto por samambaias do mangue e por espécies de mangue botão, sem a presença de dossel, o que, caso contrário, poderia evitar que a temperatura do ar diminuísse ou se elevasse demais. Com isso, P1 apresentou, ainda, as maiores amplitudes térmicas durante o período (15/08 a 14/10/05), 26,7ํ C.

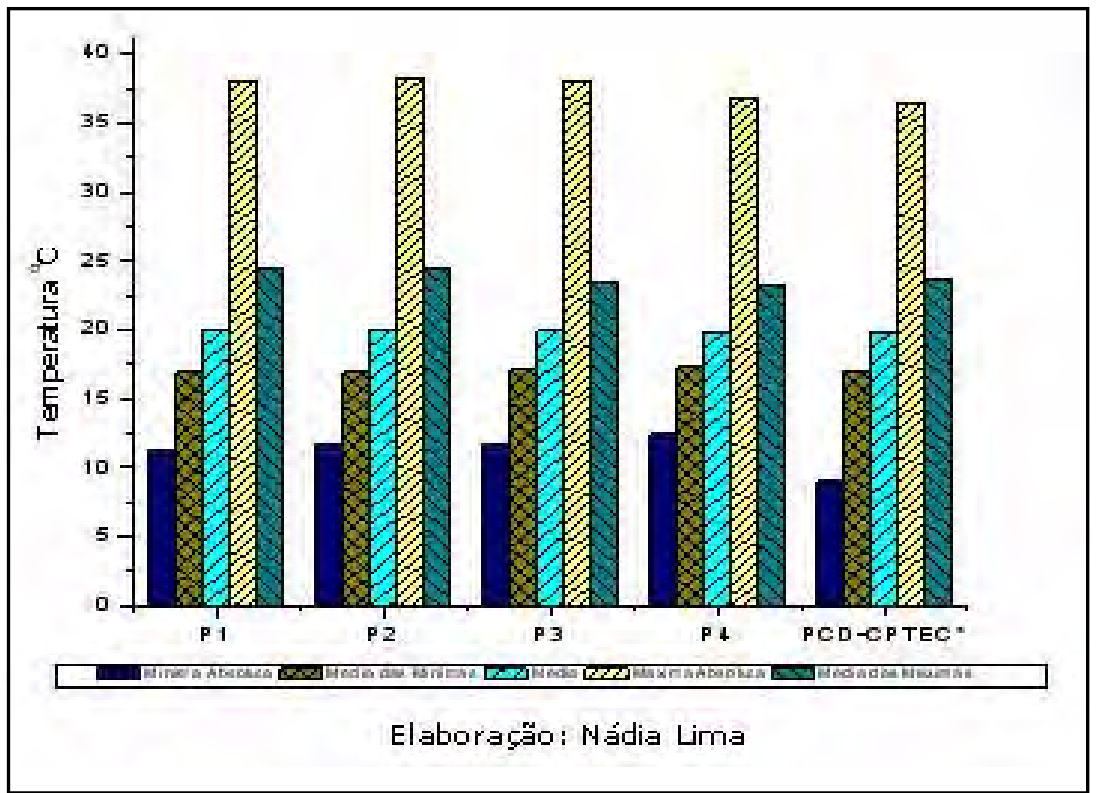

Figura 3: Temperatura média, máxima e mínima absolutas sem distinção diária ou horária para os postos da Barra do Ribeira e a PCD-Iguape - 15/08 a 14/10/05 Iguape/SP. 
O Posto 4 apresentou condições de maior estabilidade térmica, evitando que a temperatura diminuísse ou se elevasse em demasia, como pode ser observado pela máxima absoluta de $36,8^{\circ} \mathrm{C}$, apresentando, em média, uma diferença de $1,2^{\circ} \mathrm{C}$ entre os demais postos, o que pode ser explicado devido sua maior proximidade com um curso d'água, afluente do Rio Ribeira, o que o torna mais vulnerável à ação da maré diariamente, e por, também, estar localizado em solo permanentemente encharcado e sob um dossel mais denso e fechado. P4 apresentou, ainda, a menor amplitude térmica do período, 24,3ํㅡ.

O Posto 2 apresentou a maior temperatura máxima absoluta durante o período, $38,2^{\circ} \mathrm{C}$, apesar da maior temperatura máxima ser esperada para $\mathrm{P} 1$, já que estava localizado em ambiente aberto, o que facilitou a perda de calor e a entrada de radiação, refletindo diretamente na temperatura do ar, enquanto P2 apresentavase embaixo de um dossel. Entretanto, P2 por estar envolto por vegetação arbórea, apresentava-se menos ventilado que $P 1$, o que pode ter influenciado as temperaturas do ar de P2.

O Posto 3 apresentou temperatura máxima absoluta de $38,1 ㅇ ㅡ$, inferior à máxima absoluta de $\mathrm{P} 2$, e isso pode ser explicado devido P3 estar localizado a $6 \mathrm{~m}$ de altura em relação à superfície do solo, enquanto P2 localizava-se a uma altura de $1,30 \mathrm{~m}$, recebendo maior aquecimento, já que a atmosfera se aquece a partir da superfície.

Com os dados obtidos pela PCD-Iguape, foi possível relacioná-la com os demais postos. $\mathrm{Na}$ figura 05 percebe-se que a PCD-Iguape apresentou a menor temperatura mínima absoluta do período, com $9{ }^{\circ} \mathrm{C}$, e a menor máxima absoluta, com $36,5^{\circ} \mathrm{C}$, quando comparadas com os postos localizados no manguezal. Isso ocorre pelas características de localização da PCDIguape, que obedece às condições de referência (padrão) para medidas meteorológicas e climatológicas. A condição padrão para a medida de temperatura do ar é que seja coletada sobre uma área plana (topoclima) e gramada (microclima), sendo a temperatura do ar registrada em locais diferentes, conseqüência apenas do macroclima. A altura medida é entre 1,5 a 2,0 m acima da superfície, dentro de um abrigo meteorológico que permite a livre passagem do ar, mas impede a incidência direta de radiação solar nos equipamentos. Já os abrigos meteorológicos, instalados ao longo do ecossistema manguezal, encontram-se com particularidades de localizações, o que contribui para as diferenças apresentadas pelos postos.

\section{A - Variação horária da Temperatura do ar.}

Com a análise da figura 4 verificou-se que a variação média horária da temperatura do ar confirmou a aproximação do ritmo de aquecimento e resfriamento dos postos distribuídos.

Os dados de todos os postos responderam a variação horária da temperatura do ar, na qual se observa que a máxima temperatura média ocorreu com uma defasagem de uma a duas horas em relação ao horário de maior irradiância solar. Quanto a mínima temperatura média, observou-se que nos quatro postos ocorreram pouco antes do nascer do sol, isso devido à perda de energia constante a que o solo é submetido desde que o sol se põe, passando a se resfriar logo após.

O Posto 3 se destacou por apresentar as maiores temperaturas médias no período de resfriamento noturno, a partir das 17 horas até as 10 horas do dia seguinte. No entanto, durante o período de aquecimento, verificou-se que o P2 destacou-se com as maiores temperaturas do ar em relação a P3, e isso ocorre devido a P2 estar localizado mais próximo do solo. O aquecimento da atmosfera ocorre por transporte de calor, da superfície para a atmosfera, sendo o gradiente térmico atmosférico decrescente com a altitude o que faz com que o sensor mais próximo do solo (P2), registre as maiores temperaturas. Isso mostra,,ainda, que as maiores temperaturas, ou os meios mais altamente energéticos, se situam junto às proximidades da superfície, onde se localizam plantas e animais. O Posto 4 se resfria e se aquece menos em virtude de estar instalado em um ambiente com a presença de um dossel denso e fechado, o que contribui para uma maior estabilidade térmica. 


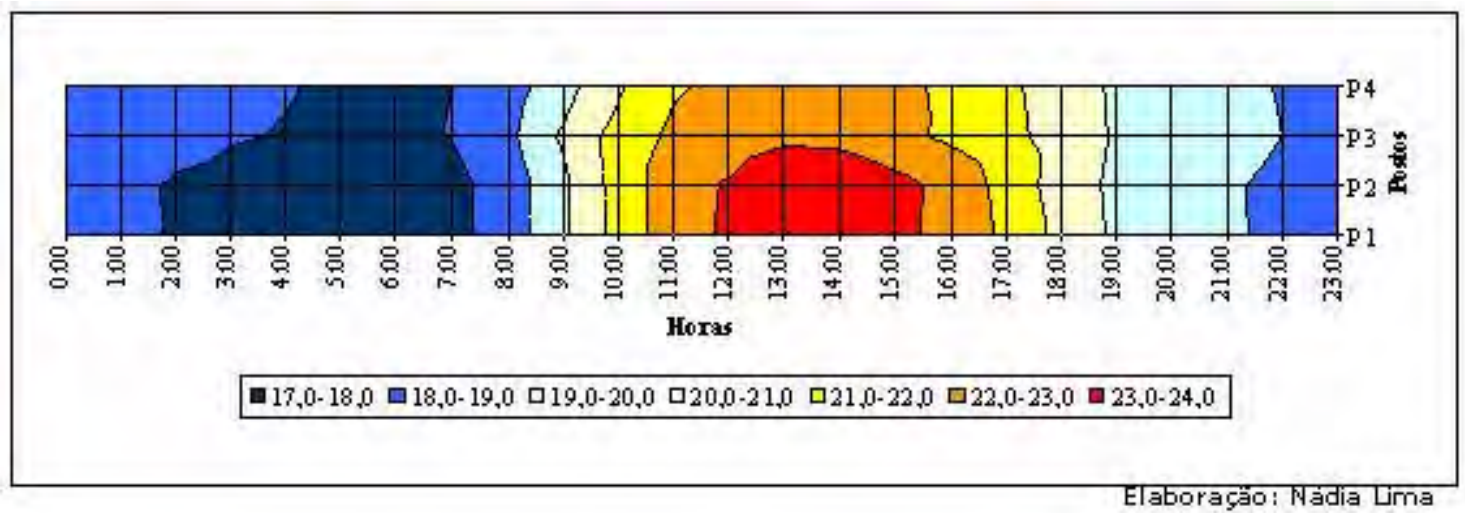

Figura 4: Variação horária da temperatura média do ar (으) - 15/08/ 05 a 14/10/05 - Barra do Ribeira - Iguape/SP

\section{B - Variação diária da temperatura do ar}

De acordo com Pereira et al (2002), as variações temporais e espaciais da temperatura do ar são condicionadas pelo balanço de energia na superfície. Assim, todos os aspectos que afetam o balanço de energia na superfície influenciam também a temperatura do ar.

Para a análise diária da temperatura do ar foram escolhidos alguns dias do período de medições, visando analisar a variação dos dados nos quatro postos sobre determinadas situações. O primeiro período compreendeu os dias 28, 29 e 30 de agosto de 2005, o qual apresentou as maiores temperaturas máximas do ar, coincidindo também com o período mais seco dos sessenta dias de medições. O segundo período escolhido, 12, 13 e 14 de setembro de 2005, correspondem aos dias com maior pluviosidade nos dias de medições.

A temperatura do ar à superfície apresenta um ciclo diário passando por um máximo e por um mínimo diário. Em situações normais, o valor máximo ocorre cerca de 2 horas depois da culminação do Sol e o mínimo acontece pouco antes do nascimento do Sol. A presença de fenômenos capazes de perturbar o estado prevalecente da atmosfera (como uma invasão de ar frio, por exemplo) pode alterar a expectativa quanto aos horários prováveis de ocorrência das temperaturas extremas.

Com a análise da figura 5 foi possível observar que os quatro postos apresentaram comportamentos semelhantes durante um período seco (28/ 08 a 30/08/05), respondendo ao ciclo de aquecimento diurno e de resfriamento noturno, característicos de dias com estabilidade atmosférica. Observa-se, também, que os postos apresentaram a temperatura máxima do ar para cada dia em torno de 2 horas depois em relação ao horário de maior irradiância solar (12 horas). Quanto à temperatura mínima, os quatro postos registraram-na pouco antes do nascer do sol, já que nesse horário o solo se encontra com a menor energia possível. Observou-se, ainda, que durante um período chuvoso não há um ciclo constante, o que ocorre devido a grande instabilidade atmosférica presente nesses dias, enquanto no período seco percebe-se o inverso. 

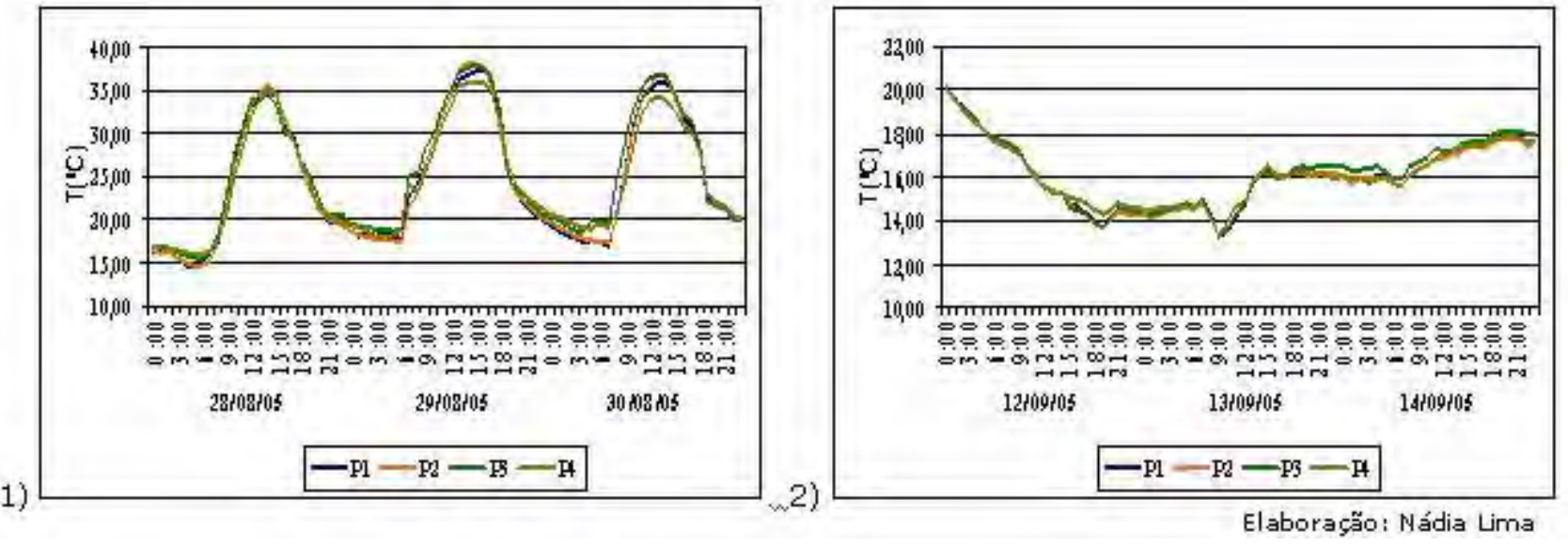

Figura 5: Variação diária da temperatura do ar dentro de um manguezal durante um período seco (1) e durante um período chuvoso (2) - Barra do Ribeira - Iguape/SP

\section{2) Umidade Relativa do Ar}

A existência de água na atmosfera e suas mudanças de fase desempenham um papel muito importante em vários processos físicos, como o transporte e a distribuição de calor na atmosfera, a evaporação e a evapotranspiração, a absorção de diversos comprimentos de onda da radiação solar e terrestre, etc.

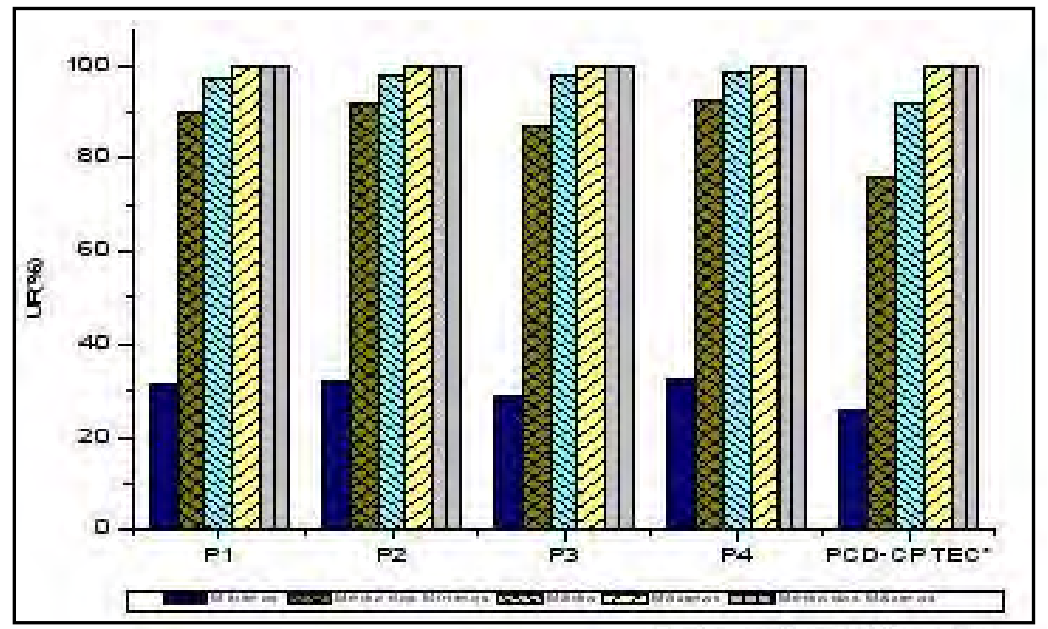

Elaboração: Nádia Lima

Figura 6: Umidade relativa média, máxima e mínima absolutas sem distinção diária ou horária para os postos da Barra do Ribeira e a PCD-Iguape - 15/08 a 14/10/05 - Iguape/SP. 
Na figura 6 é possível verificar que P4 apresentou os maiores valores de umidade relativa do ar para o período. O dossel fechado desse posto garantiu que a umidade fosse mantida no volume de ar interno do manguezal, bem como diminuiu a entrada de radiação solar, reduzindo o aquecimento do solo e o conseqüente aquecimento do ar. P4 é, ainda, constantemente atingido pela ação da maré devido à sua proximidade com o curso d'água, afluente do Rio Ribeira, e que deságua bem próximo de sua foz, apresentando um solo permanentemente encharcado.

Os menores valores de umidade relativa do ar foram registrados na PCD-Iguape, fato esse esperado devido a suas características de localização, já que está instalada sobre um gramado. P1 também apresentou valores menores quando comparados com os demais postos. Entretanto, P1, por se localizar em solo mais encharcado e por receber a influência, mesmo que periodicamente, da maré, apresentou umidade relativa maior que a PCDIguape.
O posto P3, quando comparado com P2, apresentou umidades relativas menores, isso devido P3 estar localizado a uma altura de $6 \mathrm{~m}$ da superfície, ultrapassando o dossel da vegetação, recebendo, portanto, menos influência da proximidade do solo.

Nota-se, ainda, que as máximas absolutas de umidade relativa, bem como a média das umidades relativas para o período em todos os postos, incluindo a PCD-Iguape, esteve em seu limite máximo, ou seja, 100\%.

\section{A - Variação horária da Umidade Relativa do ar}

A figura 7 ilustra a variação média horária da umidade relativa nos quatro postos de medições. Nota-se que, em média, a umidade relativa é elevada nos quatro postos de medições, devido a proximidade dos postos com o rio Ribeira de Iguape, bem como do Oceano Atlântico.

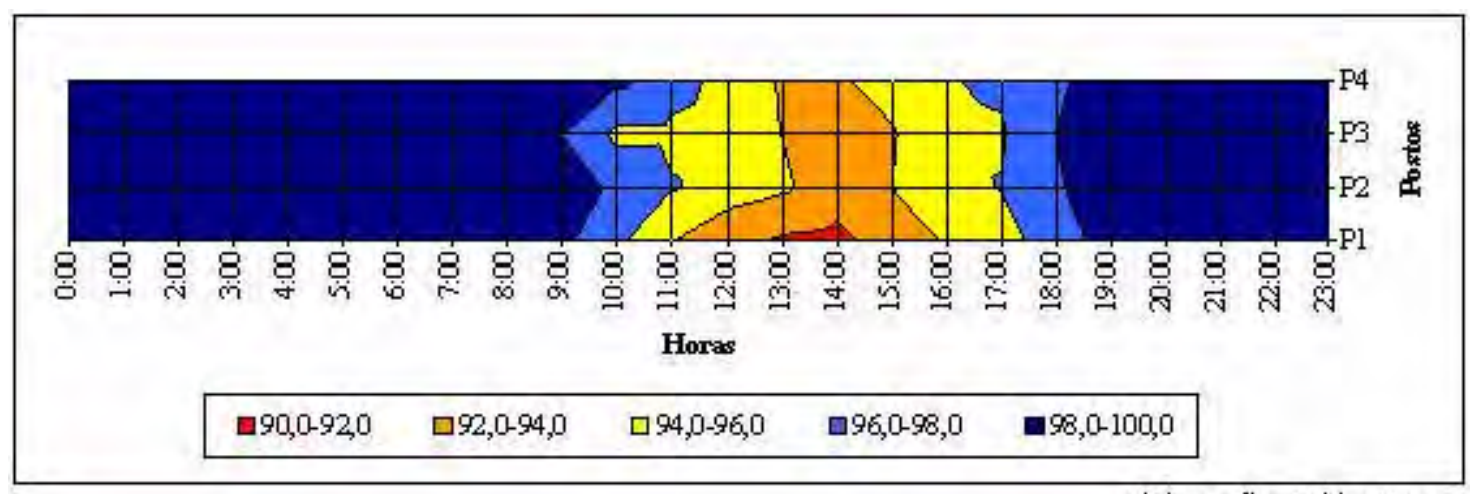

Elaboraç̃o: Nádia Lima

Figura 7: Variação horária da umidade relativa média do ar (으) - 15/08/05 a 14/10/05 Barra do Ribeira - Iguape/SP

Observa-se, ainda, que durante o período de aquecimento, P1 apresentou as menores umidades relativas do ar, entre 90 a $94 \%$, a partir das $11 \mathrm{~h}$, iniciando seu período de elevação em torno das $16 \mathrm{~h}$, portanto, um período de 5 h. Já P3 apresenta valores de umidades relativas menores, entre 92 a 94\%, a partir das $13 \mathrm{~h}$ até, aproximadamente, às $15 \mathrm{~h} 10 \mathrm{~min}$, portanto mais de $2 \mathrm{~h} 10 \mathrm{~min}$. 
P2 apresentou os menores valores de umidade relativa do ar, entre 92 a 94\%, depois das $13 \mathrm{~h}$, iniciando seu período de elevação em torno das $15 \mathrm{~h}$, portanto, por menos de duas horas no dia a umidade apresentou-se com valores mais baixos. P4 apresenta seus valores mais baixos, entre 92 a $94 \%$, também em torno das $13 \mathrm{~h}$, porém até as $14 \mathrm{~h} 30 \mathrm{~min}$, portanto, 1 h30 min apenas. Esse comportamento é esperado pela presença de dossel em P2 e P4. Além disso, tanto P2 quanto P4 apresentavam solo mais encharcado que os demais postos, contribuindo para uma elevação da umidade relativa do ar.

\section{B - Variação diária da Umidade Relativa do ar}

Para a análise diária da umidade relativa do ar foram escolhidos os dias 28, 29 e 30 de agosto de 2005, período de maiores temperaturas do ar, correspondendo, também, a um período com ausência de precipitação, mesmo período utilizado para a análise da temperatura do ar. O segundo período, 02, 03 e 04 de setembro de 2005, corresponde aos dias com menores temperaturas mínimas. Para a análise da umidade relativa do ar não se utilizou o segundo período, utilizado para a temperatura do ar $(12,13$ e 14 de setembro de 2005), pois esse período correspondia ao de maior pluviosidade, no qual a umidade relativa do ar foi de $100 \%$ ao longo dos dias.

Assim como a temperatura do ar, a umidade relativa apresenta um ciclo diário passando por um máximo e por um mínimo. Em situações normais, a umidade relativa do ar apresenta um ritmo oposto ao da temperatura do ar. Entretanto a presença de fenômenos atmosféricos é capaz de perturbar essa relação. Percebe-se ,também, que o dia com a mínima umidade relativa do ar foi o dia 29/08/05. Os quatro postos apresentaram comportamentos semelhantes durante um período seco (28/08 a 30/08/05), com as mínimas umidades relativas do ar ocorrendo em torno das 14 horas, quando ocorre a máxima temperatura diária. Durante o período de temperaturas mínimas e intensa pluviosidade, não houve um ritmo entre os dias, o que pode ter ocorrido devido à presença de instabilidade atmosférica nesses dias (Figura 8). Entretanto, para se ter certeza seria necessária a análise das cartas sinóticas dos referentes dias o que não foi realizado nesse trabalho.
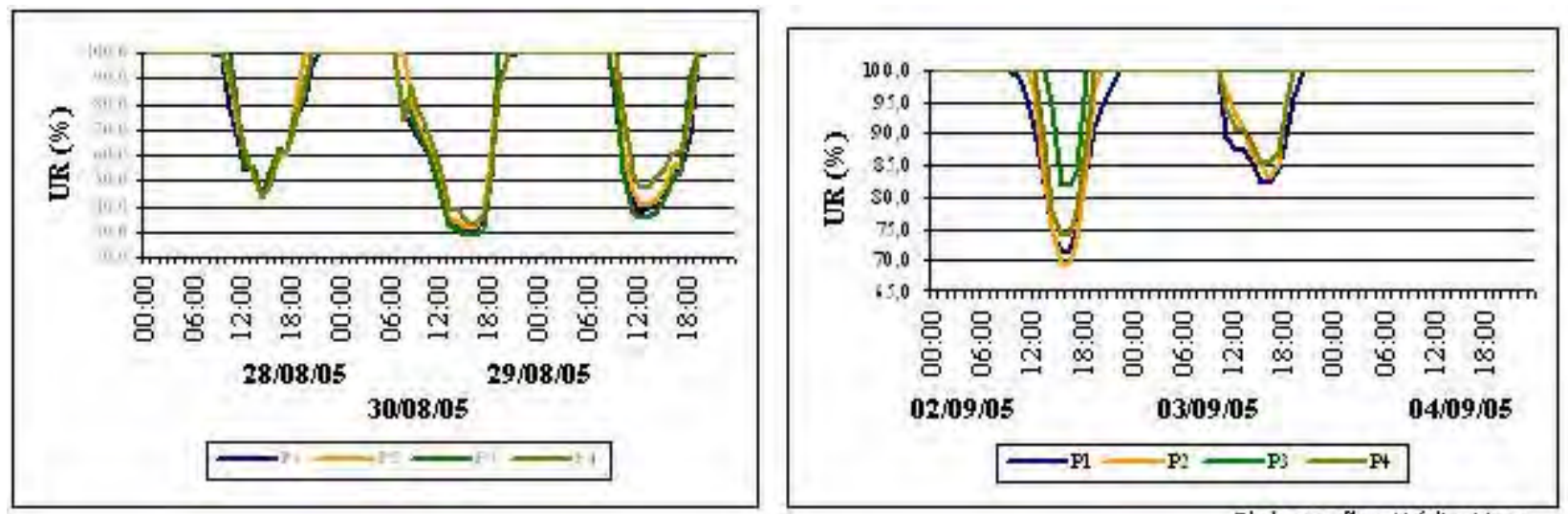

Figura 8: Variação diária da umidade relativa do ar durante um período de temperaturas máximas do $\operatorname{ar}(1)$ e durante um período de temperaturas mínimas do ar - Barra do Ribeira Iguape/SP 


\section{3) Radiação}

Com a interpretação das tabelas 2 e 3 verificou-se que P1 recebeu a maior energia no período, devido ao fato de não apresentar dossel. Enquanto P2 apresentou as menores medidas, pois a presença de dossel interceptou a radiação global. Os dados foram levantados nos dias 13 de agosto e 10 de setembro de 2005, às 13 horas.

Tabela 2: Radiação solar global (Qg) e radiação solar refletida (Qr) para o dia 13/08/05, às 13 horas, Barra do Ribeira - Iguape/SP

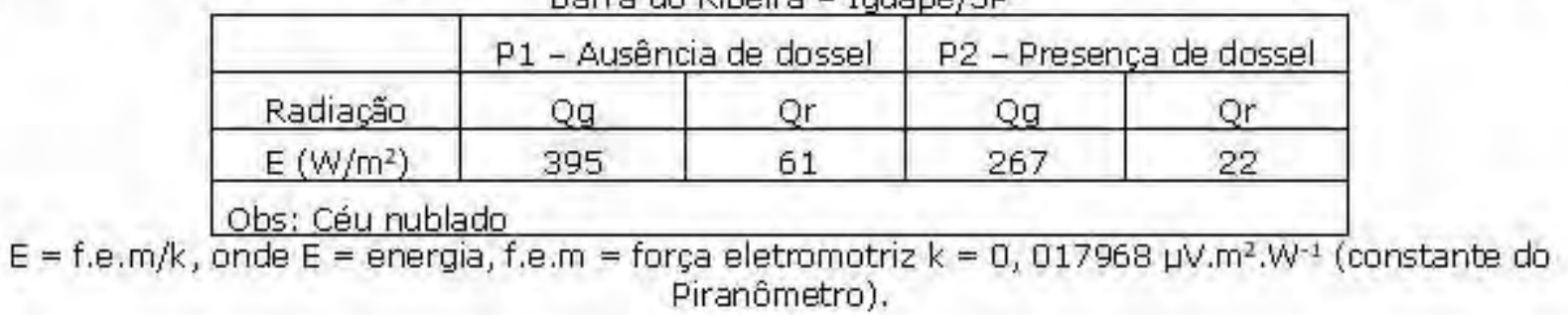

Tabela 3: Radiação Global e Radiação Refletida para o dia 10 de setembro de 2005, às 13 horas, Barra do Ribeira - Iguape/SP

\begin{tabular}{|c|c|c|c|c|}
\hline & \multicolumn{2}{|c|}{$P 1-$ Ausência de dossel } & P2 - Presença de dossel \\
\hline Radiacão & Qg & Qr & Qg & Qr \\
\hline $\begin{array}{c}\text { f.e.m } \\
(\mathrm{m} V)\end{array}$ & 12,9 & 1,2 & 4,9 & 0,4 \\
\hline E (W/m²) & 718 & 67 & 273 & 22 \\
\hline
\end{tabular}

$E=f . e \cdot m / k$, onde $E=$ energia, f.e. $m=$ força eletromotriz $k=0,017968 \mu \mathrm{V} \cdot \mathrm{m}^{2} . \mathrm{W}^{-1}$ (constante do Piranômetro).

No dia 13/08/05, com o céu nublado, o dossel de P2 promoveu uma forte redução na radiação global, se comparada com os valores obtidos em P1, apresentando uma redução de $32 \%$. Para o dia 10/09/05, com céu aberto, quando a radiação que chega à superfície é ainda maior, a diferença entre os postos se sobressaiu ainda mais, com P2 apresentando uma redução na radiação global de $65 \%$. Quanto à radiação refletida, P2 também apresentou a menor refletividade, apresentando uma diferença em relação a $\mathrm{P} 1$ de $64 \%$ no dia $13 /$ 08/05 e de $67 \%$ no dia 10/09/05.

Com isso, pôde-se perceber que a radiação solar que passa através do dossel tende a se reduzir à medida que aumenta a densidade do dossel do bosque, influenciando no total de energia acumulada no interior do bosque, onde, durante o dia, em resposta ao efeito de proteção do dossel, há uma redução na energia acumulada, mas em compensação durante a noite, a perda é menor.

Outra análise realizada foi a comparação dos valores obtidos em um mesmo posto para dias diferentes, ou seja, sua variação em dia nublado (13/08/05) e em dia de céu aberto $(10 / 09 / 05)$. O posto $P 1$, no di 13/08/05, às 13 horas, recebeu $395 \mathrm{~W} / \mathrm{m} \mathrm{n}$ de radiação solar global, enquanto que para o mesmo horário no dia 10/09/05, a medida foi de $718 \mathrm{~W} / \mathrm{m}^{2}$, o que equivale a um aumento de $45 \%$ na radiação solar global incidente. Já o posto P2, no dia 13/08/05, recebeu $267 \mathrm{~W} /$ $\mathrm{m}^{2}$ de radiação global, enquanto no 10/09/05 
registrou-se $273 \mathrm{~W} / \mathrm{m}^{2}$, com um aumento de $2 \%$ na radiação solar global incidente. Para a radiação refletida houve um comportamento parecido principalmente para o P1, apresentando, em dia de céu aberto $8 \%$ de aumento na refletividade, enquanto o Posto 2 não apresentou variação para o período em questão.

Quando a radiação direta chega à superfície, ou quando a radiação difusa consegue ultrapassar o dossel, parte é refletida, sendo denominada de coeficiente de reflexão ou albedo da superfície, enquanto a outra parte é absorvida e, portanto, transformada em calor que passará a influenciar a temperatura do ar. Com os dados obtidos em campo obteve-se a tabela 4:

Tabela 4: Coeficiente de reflexão (Albedo) para o manguezal da Barra do Ribeira-Iguape/SP $13 / 08 / 05$ e $10 / 09 / 05$

\begin{tabular}{|l|c|c|}
\hline \multicolumn{3}{|c|}{ Albedo } \\
\hline Data & \multicolumn{2}{|c|}{$13 / 8 / 2005$} \\
\hline $\begin{array}{l}\text { Posto } \\
\text { Qr/Qg } \times \\
100\end{array}$ & $\begin{array}{c}\text { (ausência de } \\
\text { dossel) }\end{array}$ & $\begin{array}{c}\text { 2 (presença de } \\
\text { dossel) }\end{array}$ \\
\hline \multicolumn{2}{|c|}{$10 / 9 / 2005$} \\
\hline $\begin{array}{l}\text { Qr/Qg } \times \\
100\end{array}$ & $15,5 \%$ & $8,3 \%$ \\
\hline
\end{tabular}

Qr: radiaç̃o refletida - Qg: radiação global

Para medir a radiação refletida, utilizouse o mesmo piranômetro de termopar de forma invertida. No entanto, quando se utiliza apenas um aparelho, ao final da coleta de dados os valores de Qg e Qr são pontuais e horários, podendo apresentar algumas variações devido ao tempo decorrido, mesmo que de segundos, entre as medidas, pois podem sofrer interferência de determinados fatores, como, por exemplo, o aumento da nebulosidade durante a inversão do aparelho, influenciando na quantidade de radiação que chegou ao ambiente. $\mathrm{Na}$ tabela 4 observa-se que. mesmo o albedo sendo uma propriedade da superfície, há uma variação na porcentagem entre o dia 13/08 e 10/09/2005. Entretanto, de acordo com Pereira et al. (2002), solos escuros apresentam como coeficiente de reflexão uma porcentagem de 5 a $15 \%$. Portanto, tanto no dia $13 / 08$ quanto no dia $10 / 09 / 05$, as medidas se apresentaram dentro do esperado.

\section{4) Pluviosidade}

Os pluviômetros instalados em P1 e P2 ficaram em campo durante todo o período de coleta dos dados (60 dias), quantificando, assim, a chuva no período de 15/08 a 14/10/ 05. O pluviômetro PL1 foi instalado em P1, local que permitia uma livre recepção de toda e qualquer precipitação que chegasse durante o período em questão, enquanto o pluviômetro PL2 foi instalado em P2, sofrendo influência direta do dossel arbóreo. Todo o volume armazenado nos postos foi quantificado por meio de três beckeres volumétricos de capacidades diferentes $(1000 \mathrm{ml}, 250 \mathrm{ml}$ e 50 $\mathrm{ml})$.

A equação utilizada para o cálculo do volume do reservatório foi: $V=ð . r^{2} . h$, onde $V$ é o volume de chuva que se deseja reter, h é a altura do reservatório e $r$ é o raio da base do reservatório. Neste caso, o volume de chuva 
retirado do reservatório, que se apresenta em mililitros $(\mathrm{ml})$, ainda precisa ser convertido em milímetros $(\mathrm{mm})$, então, partindo do princípio que $1 \mathrm{~mm}=1 \mathrm{l} / \mathrm{m}^{2}$, transforma-se as unidades de medida de volume (de $\mathrm{ml}$ para l, dividindo-a por 1000) e da área de captação do funil (de $\mathrm{cm}^{2}$ para $\mathrm{m}^{2}$, dividindo-a por 10000), ou segundo a fórmula apresentada na tabela 5 .

Tabela 5: Precipitaçã̃o ocorrida durante o periodo 15/08 a 14/10/05 no manguezal da Barra do Ribeira e na Plataforma de Coleta de Dados (CPTEC)-Iguape, Iguape/SP

\begin{tabular}{|c|c|c|c|}
\hline Pluviosidade & P1 - Ausência de & P2 - Presença de \\
dossel & $\begin{array}{c}\text { PCD- } \\
\text { Iguape }\end{array}$ \\
\hline $\mathrm{ml}$ (mililitros) & 7335 & 6081 & $-\cdots$ \\
\hline $\begin{array}{c}\mathrm{mada}=(\mathrm{ml} / 1000) / \\
\left(n, r^{2} \text { funil } / 10000\right)\end{array}$ & 444 & 368 & 486 \\
\hline
\end{tabular}

O pluviômetro PL1 armazenou um volume de $7.335 \mathrm{ml}$, o que equivale a uma chuva de $444 \mathrm{~mm}$ em dois meses. Enquanto o pluviômetro PL2 armazenou um volume de $6.081 \mathrm{ml}$, equivalendo a $368 \mathrm{~mm}$ no mesmo período. Com esse dados foi possível quantificar a interceptação do manguezal em relação à chuva, com uma interceptação de $17 \%$, o que equivale a $76 \mathrm{~mm}$.

Ao comparar os dados obtidos com PL1 e os dados obtidos com a PCD-Iguape, percebeu-se que, mesmo ambos instalados em ambientes sem obstrução para a chegada da pluviosidade, obteve-se uma diferença nos resultados das medições. A PCD-Iguape quantificou, para o período em consideração (60 dias), $486 \mathrm{~mm}$, contra 444 $\mathrm{mm}$ de PL1, uma diferença de $9 \%$, equivalendo a $42 \mathrm{~mm}$. Entretanto é necessário considerar que a abertura do funil instalado em PLl é maior do que a do instalado na PCD-Iguape, o que provavelmente, facilitou a saída de água do armazenamento por meio da evaporação, enquanto na PCD-IGUAPE a perda é mínima, contribuindo para uma maior exatidão nos dados medidos, o que, possivelmente, contribui para essa diferença.

Ao se comparar o pluviômetro PL2 com a PCD-Iguape, as diferenças foram ainda maiores, com uma diferença de $24 \%$.
O que, vem mais uma vez, comprovar a importância da vegetação como um dos principais controladores climáticos, principalmente quando a escala de trabalho é a microclimática.

\section{Considerações Finais}

Ao comparar os dados estruturais da vegetação e relacioná-los com os atributos climáticos, confirmou-se a importância da vegetação como controlador climático, principalmente quando a escala de trabalho é a microclimática.

A Parcela 1 (P1) apresentou o menor diâmetro médio e a menor altura média quando comparada com as demais parcelas. Observou-se que nessa parcela há um maior espaçamento entre os indivíduos, contribuindo para que não se formasse um dossel. Com isso, conclui-se que o desenvolvimento estrutural da Parcela 1 é o mais baixo se comparado com as demais parcelas. A ausência de dossel contribuiu para que os atributos climáticos registrados fossem mais intensos, com valores de temperaturas máximas elevadas, temperaturas mínimas intensas, menores valores de umidade relativa do ar, intensos valores de radiação e um elevado registro de pluviosidade. 
A Parcela 2 ( P2 e P3) se destacou com uma quantidade elevada de indivíduos e troncos. No entanto, as árvores se apresentaram com diâmetro médio e altura média superiores ao da Parcela 1 , refletindo um desenvolvimento estrutural maior. Os espaçamentos entre os indivíduos colaborou para a formação de um dossel, porém um dossel pouco denso. Esse fato refletiu nos atributos climáticos registrados em $\mathrm{P} 2$, os quais sofreram uma pequena atenuação nos valores quando comparados com o P1 (Parcela 1), registrando temperaturas máximas menos elevadas, temperatura mínima menos intensa, umidades relativas maiores e interceptação da radiação global e da pluviosidade. Vale lembrar que o Posto 3 localizava-se fora desse dossel, sofrendo mais intensamente o efeito da altura em relação à superfície, bem como de uma maior ventilação em relação ao $\mathrm{P} 2$.

A Parcela 3 (P4) foi a única parcela a apresentar um bosque misto (Rhyzophora mangle e Lacungularia racemosa). Essa parcela apresentou elevado desenvolvimento estrutural, principalmente para as espécies de Rhyzophora mangle, com diâmetro médio superior a $10 \mathrm{~cm}$ e altura média superior a $6 \mathrm{~m}$, além de um menor número de indivíduos por parcela. Essa parcela apresentou a formação de dossel denso e fechado, contribuindo para que os valores dos atributos climáticos presentes no P4 registrassem uma estabilidade térmica, elevados valores de umidade relativa do ar e amplitude térmica reduzida.

O Posto 4, mais uma vez, confirmou a importância da vegetação como atenuadora das variações térmicas acentuadas durante o dia, enquanto P1, desprovido de dossel, intensificou o efeito microclimático, tanto no aquecimento diurno como no resfriamento noturno, apresentando menor estabilidade térmica. Superfícies com maior presença de água, como P4, também produzem efeito moderador no microclima, contribuindo para um ambiente mais úmido e com umidades relativas elevadas. Quanto à permeabilidade à entrada e saída de radiação nos ambientes microclimáticos, conclui-se que P4, devido estar localizado sobre um dossel denso e fechado, recebeu menos influência da radiação direta, apesar de não se ter quantificado a radiação nesse posto.

Quanto a pluviosidade, comprovou-se que o posto com dossel (P2) apresentou uma interceptação considerável ao se comparar com o posto sem o dossel (P1). Provavelmente, caso o pluviômetro tivesse sido instalado em $\mathrm{P} 4$, a interceptação da chuva seria ainda maior devido ao dossel mais denso e fechado a que o posto estaria submetido.

É necessário frisar que, para a compreensão dos microclimas, de forma a representar mais fielmente a realidade, seria importante, em estudos posteriores, a realização de uma análise mais detalhada dos sedimentos presentes na área de estudo, por meio de uma análise granulométrica, como forma de melhor caracterizar os sedimentos em sua composição, pois a composição e a côr do sedimento influência as características microclimáticas do ambiente. É necessário, ainda, a realização de um estudo da influência das marés numa abordagem mais detalhada, levando em consideração a maré meteorológica, registrando pontualmente a sua variação e sua influência em todos os postos.

Concluiu-se que a vegetação fixada em um ponto da superfície depende das condições climáticas locais, que podem ser favoráveis ou desfavoráveis à sua vida, mas a vegetação também exerce uma influência no microclima, que aumenta na medida em que a vegetação se desenvolve e que o dossel se fecha pelo desenvolvimento das plantas. 


\section{Bibliografia}

ARMANI, G. Interações entre a atmosfera e a superfície terrestre: variações da temperatura e umidade na bacia B do Núcleo Cunha (IF) SP. São Paulo, 2004. Dissertação (Mestrado em Geografia Física) - FFLCH, Universidade de São Paulo, São Paulo, 2004.

ARMANI, G.; GALVANI, E. avaliação do desempenho de um abrigo meteorológico de baixo custo. Artigo submetido a publicação na Revista Brasileira de Agrometeorologia, fevereiro de 2005 (no prelo).

BERTRAND, G. Paisagem e geografia física global: esboço metodológico. Trad. Olga Cruz. Caderno de Ciências da Terra, São Paulo, Inst. de Geografia, Universidade de São Paulo, 13, 1971.

CINTRÓN, G.; SHAFFER-NOVELLI, Y. Guia para estudo de áreas de manguezal - estrutura, função e flora. São Paulo: Caribbean Ecological Research, 1986.

CUNHA-LIGNON, Marília. Dinâmica do manguezal no sistema de Cananéia-Iguape, Estado de São Paulo - Brasil. São Paulo, 2001. Dissertação (Mestrado em Oceanografia) - Instituto Oceanográfico, Universidade de São Paulo, São Paulo, 2001.

DIEGUES, A. C. S. Povos e águas - inventário das áreas úmidas brasileiras. 2. ed. São Paulo: NUPAUB/USP, 2002.

DINIZ, Amarildo; FURLAN, Sueli A. Relações entre classificações fitogeográficas, fitossociologia, cartografia, escalas e modificações sócio-culturais no Parque Estadual de Campos do Jordão (SP). Revista do Departamento de Geografia, São Paulo, USP, n. 12 , p.123-161, 1998.

HERZ, Renato. Distribuição dos padrões espectrais associados a estrutura física dos manguezais de um sistema costeiro subtropical. São Paulo, 1988. Tese (Livre Docência) Instituto Oceanográfico, Universidade de São Paulo, São Paulo, 1988.
MARIN, Fabio $\mathrm{R}$. et al. Solar radiation interception and its relation with transpiration in different coffee canopy layers. Revista Brasileira de Agrometeorologia, Santa Maria, v. 11, n. 1, 2003.

MILANESI, Marcos A.; GALVANI, Emerson. Pluviômetro experimental para localidades remotas. In: SIMPÓSIO BRASILEIRO DE GEOGRAFIA FÍSICA APLICADA, 11, 2005, São Paulo. Anais... Faculdade de Filosofia, Letras e Ciências Humanas, Universidade de São Paulo, 2005.

MIRANDA, Ricardo A. C. et al. Interceptação de chuva em cafezais adensados da região serrana centro-norte fluminense. Revista Brasileira de Agrometeorologia. Santa Maria, v. 12, n.2, 2004.

MONTEIRO, Carlos. A. F. Análise rítmica em climatologia: Problemas da atualidade climática em São Paulo e achegas para um programa de trabalho. Climatologia I. Instituto de Geografia, Universidade de São Paulo, 1971.

MONTEIRO, Carlos. A. F. Teoria e clima urbano. São Paulo, 1976. Tese (Livre Docência) Instituto de Geografia, Universidade de São Paulo, São Paulo, 1976.

PEREIRA, Antônio, R.; ANGELOCCl, Luiz R.; SENTELHAS, Paulo C. Agrometeorologia: fundamentos e aplicações práticas. São Paulo: Editora Agropecuária, 2002.

RODRIGUES, Cleide. A teoria geossistêmica e sua contribuição aos estudos geográficos e ambientais. Revista do Departamento de Geografia, São Paulo, n. 14, p. 69-77, 2001.

ROSS, Jurandyr L. S. Geomorfologia e geografia aplicada à gestão territorial: teoria e metodologia para o planejamento ambiental. São Paulo, 2001. Tese (Livre Docência) - FFLCH - Universidade de São Paulo, São Paulo, 2001.

ROSS, Jurandyr L. S.; MOROZ, Isabel C. Mapa geomorfológico do estado de São Paulo. Escala 1: 500.000. São Paulo: Instituto de Pesquisas Tecnológicas, v. I/II, 1997. 
ROSSI, Marcio; MATTOS, Isabel Fernandes de A. Solos de mangue do estado de São Paulo: caracterização química e física. Revista do Departamento de Geografia, São Paulo, n. 15, p. 101-113, 2002.

SECRETARIA DO MEIO AMBIENTE. Macrozoneamento do complexo estuarino-lagunar de Iguape e Cananéia: plano de gerenciamento costeiro. São Paulo: SMA, 1990.

SETTI, Denise M. O holorritmo e as interações trópico-extratrópico na gênese do clima e as paisagens do Mato Grosso. São Paulo, 2000. Tese (Doutorado em Geografia Física) - FFLCH Universidade de São Paulo, São Paulo, 2000.

SHAFFER-NOVELLI, $Y$ et al. Manguezal: ecossistema entre a terra e o mar. São Paulo: Caribbean Ecological Research, 1995.
SUGUIO, Kenitiro; TESSLER, Moysés G. Depósitos quaternários da planície de Cananéia-Iguape. São Paulo: DPNM, 1992.

TARIFA, J. R. Os fluxos Polares e as chuvas de primavera verão no estado de São Paulo. FFLCH, Universidade de São Paulo, São Paulo, 1975.

VAREJ ÃO-SILVA, Mario.A. Meteorologia e Climatologia. Recife: versão digital, 2005. <http: www.agritempo.gov.br >- acesso em 12/08/05.

Sites Consultados:

<http:www.cptec.inpe.br>. Acesso em: setembro e outubro de 2005.

<http:www.mar.mil.br>. Acesso em: 04/05/ 2005, 12/08/2005, 01/09/2005 e 03/10/2005.

<http: www.agritempo.gov.br>. Acesso em: 12/ $09 / 2005$ 